\title{
Eastern Area Power System Reinforcement study
}

\author{
Lalith A. Samaliarachchi and N. Anuradha Mudannayake
}

\begin{abstract}
The purpose of this study is to investigate methods for reinforcing the Eastern area power system by overcoming the present and future problematic conditions. In preparation of this paper, every possible effort is given to concise the contents without loosing the key topics. The study comprises three consecutive phases. The first phase consists of a comprehensive study of the Eastern area power system, finding out key problematic conditions, studying the potential solutions obtainable from within the same area under four different system operation scenarios. The second phase consists of two analytical stages. In the first stage, more concern is devoted to different types of solutions to overcome the present day problems such as the voltage droop, line overloading problems etc. Ten different types of proposals based on dependable view points, thoroughly revised with the help of power flow studies are also given in this section. The second stage search out possible solutions not only for the present but also for ten years ahead from year 2005. For the selected study period of 20052014, a series of detailed analysis have been carried out in yearly basis with remedial actions wherever seemed necessary. The final study consists of six different types of alternative solutions capable of withstanding five types of criteria under system normal condition as well as under single contingency condition. Final phase is a technoñeconomic analysis of each of the six solutions selected, for optimisation. Although not included, a series of studies on fuel transportation and an account on social \& environmental impact assessment also have been carried out which are inherently essential parts of a similar project.
\end{abstract}

Keywords: Planning Criteria, Low voltage, Overloading, Reliability

\section{Introduction}

Reduction of power quality problems especially the dropping of voltage levels, associated with the Eastern area power supply were identified many years ago through investigations carried out by the Ceylon Electricity Board (C.E.B.). From time to time, several remedial action plans and suggestions have been proposed and submitted in order to rectify the prevailing situation. Unfortunately, all such efforts whether practicable or otherwise, proved to be fruitless endeavours. But in a broader sense the C.E.B. cannot be blamed because the economic problems of allocating funds, technical and environmental impact problems of layout and finally the social attitudes along with political interests emerged as customary obstacles to hinder such efforts whenever tabled. Hence it has become one of the critical problems lying at the planning divisions of the C.E.B. Although the Eastern province consists of three districts, namely, Trincomalee, Batticaloa and Ampara on the basis of political and administrative demarcations, the study focused on finding a solution to maintain an adequate and uninterrupted flow of electricity to the inhabitants of Eastern province without restricting to the above demarcations. And also, the out come of the study should guarantee not only the present day requirements but also the future, too.

\section{Existing Problems of the Eastern Area Transmission System}

The Eastern area is fed by three main $132 \mathrm{kV}$ radial lines as clearly visualise from figure 1 . After a thorough study of present as well as past data of the Eastern area grid substations and 132 $\mathrm{kV}$ radial transmission feeders which are given in table 1, the following are identified as severe problematic conditions pertaining to the Eastern power system:

- Thermal overloading of feeder lines

- Violation of permissible voltage levels

- Low reliability

- Substation overloading

Eng. Lalith A. Samaliarachchi, B.Sc. Eng (Hons) (Morntuwn). M.Eng.(AIT). MIEE. C. Eng. Senior Leriurer. Elentrical \& Computer Deparment, Open Universily of Sri Lanka.

Mr. N.Anuradha Mudannayake, B.Terh(EngXHons) (OUSL). SIESL 


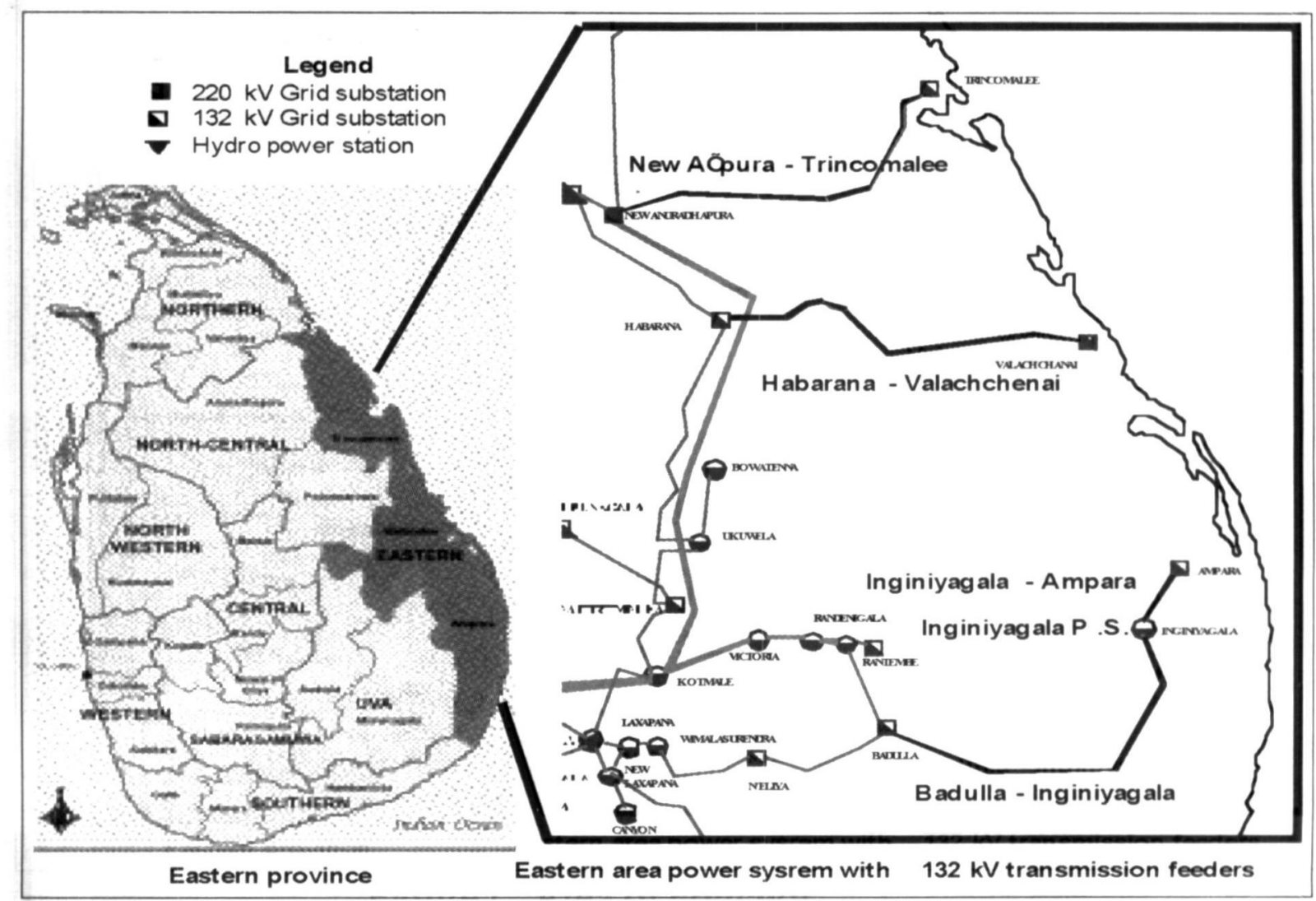

Figure 1: Area of concern

Table 1: Technical features of existing $132 \mathrm{kV}$ transmission lines

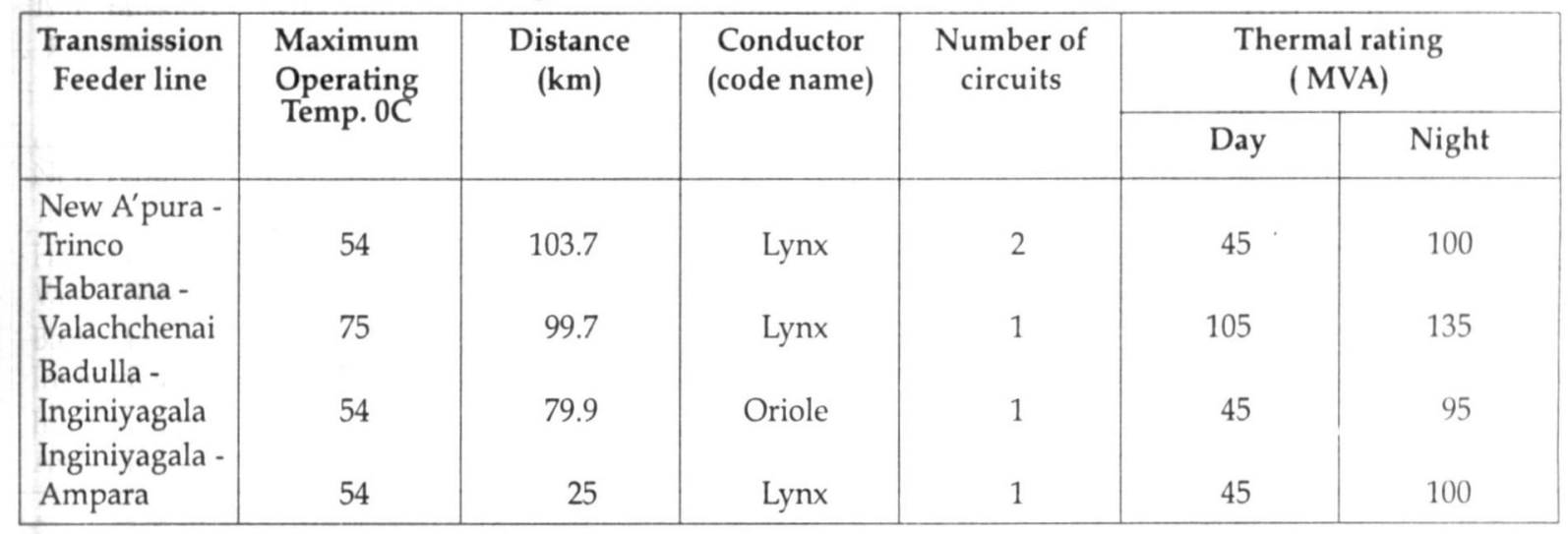

\subsection{Thermal overloading of $132 \mathrm{kV}$ feeder lines}

\subsubsection{New AnuradhapurañTrincomalee 132kV feeders}

At present Trincomalee has recorded its maximum day peak and night peak around 19.5 MVA and 32.2 MVA respectively. When compared with the characteristics behaviour of the transmission line design and load forecast, no overloading threat exists along the line even under $\mathrm{N}-1$ (single contingency), in the near future. If a drastic increase of power consumption is not experienced no special implementation is needed up to year 2014 regarding the transmission overloading.

\subsubsection{Habarana-Valachchenai $132 \mathrm{kV}$ feeder}

At present Valachchenai has recorded its maximum day peak and night peak around 8.2 MVA and 19.2 MVA respectively. When compared with the characteristic behaviour of the transmission line design and load forecast, no overloading threat exists along the line under healthy and uninterrupted feeding. Under these conditions (i.e. no breakdown of the feeder line), the transmission line will be safe to operate up to year 2014 . 
At present Inginiyagala/Ampara has recorded its maximum day peak and night peak around 20.5 MVA and 57.2 MVA respectively. Therefore according to the latest load forecast, thermal overloading threat of the existing feeder lines is most probable and may occur in and around the year 2010. Furthermore, if Madagama 132/33 $\mathrm{kV}$ grid substation (to be connected to Badulla Ampara, in-and-out) is implemented the situation might get worse.

\subsection{Violation of permissible voltage levels}

All these overhead lines are long transmission feeders thus an unavoidable voltage drooping problem is encountered by users at far ends of the Eastern area. Unfortunately the consumers belonging to Ampara and Batticaloa districts are severely affected by way of: unexpected voltage variations during the day creating problems in day to day activities, prevalence of drooped voltage level during the nights resulting inexpressible hardships for domestic users, problems associated with bulk and industrial consumers, problems associated with extension of the load consumptions etc. For the sake of clear visualizing, the graphically analysed data collection is being attached to figure 2 . Here the voltage profile of five load centres, namely, Ampara, Trincomalee, Valachchenai, Badulla and Habarana, over several years in the past, are plotted on monthly basis for the night peak loading (around 20:00 hrs). It is very obvious how much critical the problematic Ampara is. But other load centres will not experience such a critical situation in the near future and will operate under normal operating limits.

\subsection{Low reliability}

Except New Anuradhapura-Trincomalee feeder lines, the remaining long single feeders will make the Eastern area power system totally unreliable under $\mathrm{N}-1$ contingency condition.

By analysing several years in the past (table 2), following 'unavailability' results are obtained.

Table 2: Reliability factors for $132 \mathrm{kV}$ feeder lines

\begin{tabular}{|l|c|c|c|}
\hline Feeder Line & $\begin{array}{c}\text { Outage time } \\
\text { (hrs/yr) }\end{array}$ & $\begin{array}{c}\text { Failure rale } \\
\text { (Faults/yr) }\end{array}$ & $\begin{array}{c}\text { Repair rate } \\
\text { (hrs/fault) }\end{array}$ \\
\hline $\begin{array}{l}\text { New A'pura } \\
\text {-Trinco-1 }\end{array}$ & 4.3875 & 9.75 & 0.45 \\
$\begin{array}{l}\text { New A'pura } \\
\text {-Trinco - 2 } \\
\text { Badulla } \\
\text { - Ampara } \\
\text { Habarana } \\
\text {-Valachchcena }\end{array}$ & 5.1125 & 11.75 & 0.4351 \\
\hline
\end{tabular}

Trincomalce hrs/yr, Valachchenai $0.1833 \mathrm{hrs} / \mathrm{yr}$ and Ampara $8.4917 \mathrm{hrs} / \mathrm{yr}$

At this juncture the following distinctive conclusions are identified.

- Eastern area suffers a series of problems and requires the necessity of a long term solution with multidirectional views.

- When compared with other feeders, New Anuradhapura-Trincomalee feeders may well function for several years to come with no problematic condition in the vicinity. So that, the study will not investigate anything regarding further development of the New Anuradhapura- Trincomalee feeder lines.

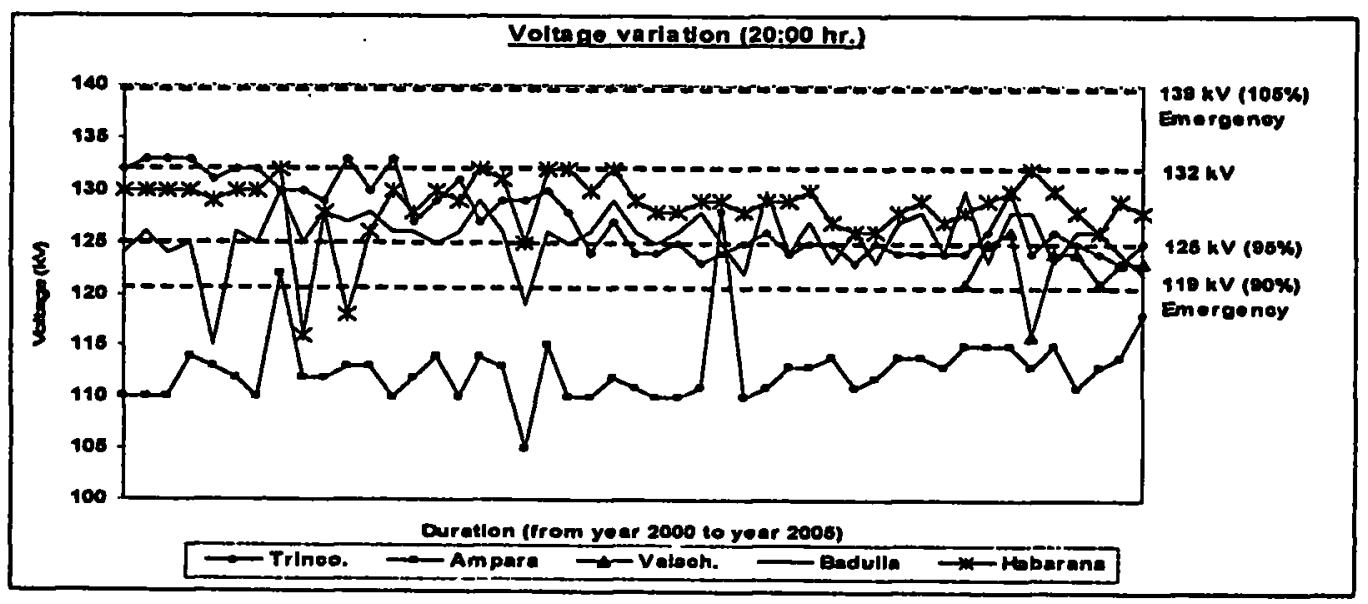

Figure 2: Voltage variation during the past few years 


\subsection{Substation overloading}

Most of the grid substations in the Eastern area seem to be violating their firm substation capacities under single contingency $(n-1)$ condition. And also Valachchenai is experiencing the overloading of transformers even under system normal condition. But there is a possibility of preventing this by transferring some of its loads to a near by grid substation as a short-term remedial action.

\section{Contribution of the Inginiyagala power station}

It is well identified as one of the most effective and critically sensitive generating point for Badulla and Ampara load centres. Although the Inginiyagala power station is fed from one of the Sri Lanka's largest irrigation tank, Sensnaynke Samudrayn, due to the following reasons the expected level of contribution cannot be obtained satisfactorily.

- Comparatively low generation capacity $\left(2^{\star}\right.$ $2.475+2 * 3.15$ total of $11 \mathrm{MW}$ )

- Lower reliability (power plant is almost outdated and lacks dependability resulting frequent breakdowns).

- No significant capacity improvement proposals are being identified

- Involvement in water management policy where by priority is given for irrigation

Figure 3, data clarification will clearly represent the power contribution level of the power plant and influence of water management policy over

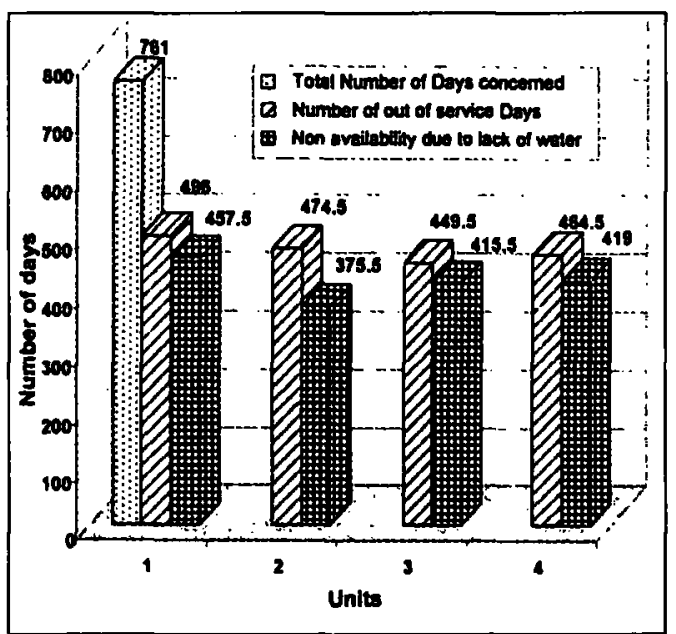

Figure 3. Contribution of the Inginiyagala power station for 2003, $2004 \& 2005$ the past several years. Therefore it is obvious that a dependable contribution cannot be expected from Inginiyagala power station. Even with full capacity, Inginiyagala power station is unable to overcome the problematic situation. So, it cannot be considered as a potential solution and its level of contribution is considered as negligible.

\section{Some of the criteria used for the technical analysis}

During the study period, the system has been put through or subjected to modifications with new addition of generators, transmission lines, load growth of each load centre etc. Hence the study included the system configuration of commissioning and decommissioning of generators, $220 / 132 \mathrm{kV}$ transmission lines, load growth of load centres, addition of new load centres and scheduled load transfer schemes. Most of the data concerned in this study including existing generator data, grid substation data, transmission line data, transformer data, active \& reactive load forecast and future generation, transmission, proposed grid substations and augmentations are all based on the CEB long-term transmission expansion plan for 2004-2014 period. Planning criteria used for this study include the voltage criteria, thermal overloading criteria, security or single contingency criteria and firm substation capacity criteria.

\section{Solution Options}

\section{1 analytical stage 1}

At this stage, concern is directed under ten different types of proposals to overcome the prevailing voltage droop problem. These ten proposals make way to uncover a number of solving methods which will be of immense use in finding a final solution. All the proposals considered at this stage have been checked under four worst case scenarios to find out the potentiality of superseding the voltage drop problem without allowing other problems to rise up at the same time. The four scenarios which have been taken into consideration are given below. By analysing the performance over future load growth for several years ahead, every aspect related to it has been noted down and further analysed. 
1) Hydro maximum day peak Hydro power plants are given priority and put into service first. The rest of the requirements needed are to be fed by thermal power plants. Normally the loading is recorded around 11:00 hours.

2) Hydro maximum night peak Hydro power plants are given priority and put into service first. The rest of the requirements needed are to be fed by thermal power plants. Normally the loading is recorded around 19:30 hours.

3) Thermal maximum day peak Thermal power plants are given priority and put in to service first. The rest of the requirements needed are to be fed by hydro power plants. Normally the loading is recorded around 11:00 hours.

4) Thermal maximum night peak Thermal power plants are given priority and put into service first. The rest of the requirements needed are to be fed by hydro power plants. Normally the loading is recorded around 19:30 hours.

Ten types of proposals which are based on three types of correction methods, namely injection of reactive power by using suitable capacitor banks, injection of active power with the help of a power station and the construction of additional transmission lines, given in appendix table 4.

\subsection{Transmission line from Valachchenai to Ampara}

As stated in several proposals, concern has been given to check the feasibility of making the Eastern area power system loop by interconnecting the two radial feeders from Valachchenai to Ampara. Regarding this, little effort has been given previously by making it difficult to find out a transmission route for the study to proceed. As such 1:50,000 maps of Vakarai, Kalkudah, Aralaganwila, Batticaloa, Mahaoya, Padirippu and Ampara ñ Kalmunai have been used for the purpose of transmission routing. Every possible effort has been taken to minimise the interferences such as cultivated private lands, densely populated areas including towns and urban localities while at the same time keeping off the coastal belt. In compliance with the above demarcations, the route selected passes over paddy fields and alongside the boundaries of reservations and sanctuaries for a distance of about $84.1 \mathrm{~km}$. Therefore an approximate length of $90 \mathrm{~km}$ is used to pave the way for planning and load flow studies to proceed. Apart from brief comments attached to each proposal given above and by considering individual performance of each project over several criteria, proposals 3, 6, 7 \& 9 were further preceded with required remedial actions.

\subsection{Analytical stage 2}

Based on individual performances, filtering and modifying the selected proposals of analytical stage 1 are considered at this stage. Since most of the proposals considered at stage 1 seemed unable to withstand or overcome the different types of problematic conditions individually, those have been modified and fortified by adding and mixing several proposals. Since the target of the research is to find out a better solution, not only to overcome the present day requirements but also for several years ahead, each solution has been checked from 2005 to 2014 under:

- System normal condition \&

- Single contingency condition Following are the facts used for the system verification.

- Violation of permissible voltage levels (voltage criteria)

- Thermal criteria

- Reliability or security criteria

- Violation of firm substation capacity (125\% overloading)

- Expected future load growth

Thus, following alternative solutions are being selected and proceeded with from 2005 to 2014.

\subsubsection{Solution 1}

Proposal 3 is being implemented from 2005 and Rantembe-Ampara transmission line is being connected to the system at the appropriate time as shown in figure 4. Remedial action schedule is given in appendix, table 5. 


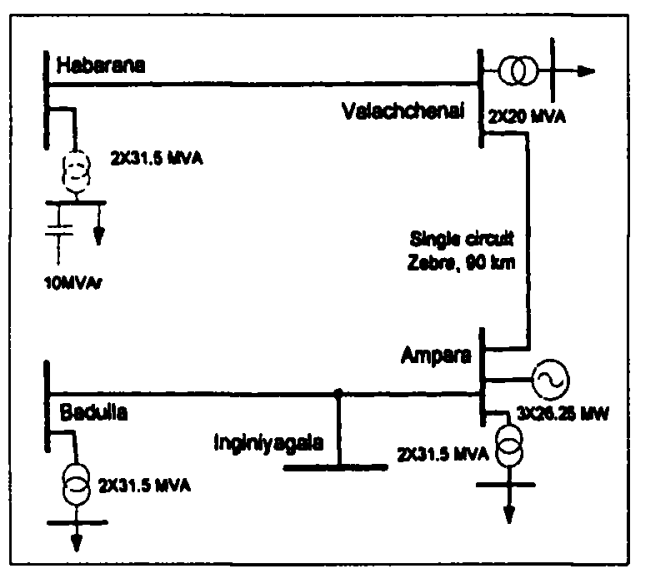

Figure 4: Initial arrangement for solution 1

\subsubsection{Solution 2}

Proposal 7 is being continued from 2005 to 2014 with two main streams and to maintain Ampara as a $132 \mathrm{kV}$ "PV bus" all the time as shown in figure 5 and figure 6.

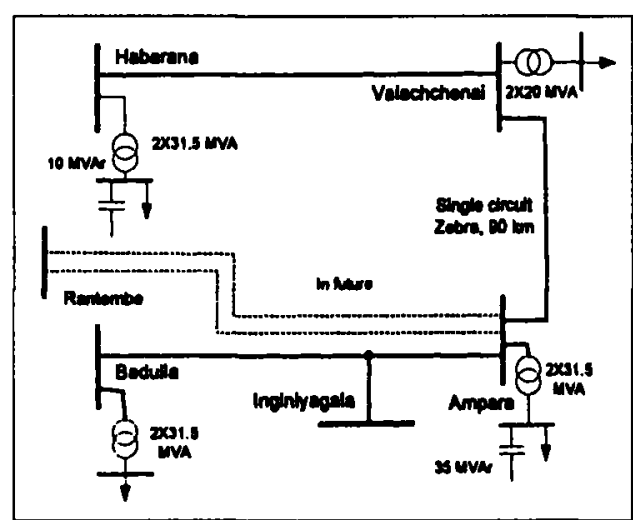

Figure 5: Initial arrangement for solution 2 (a)

Required reactive power is by generators first and then from a capacitor bank. Remedial action schedule is given in appendix, table 6 .

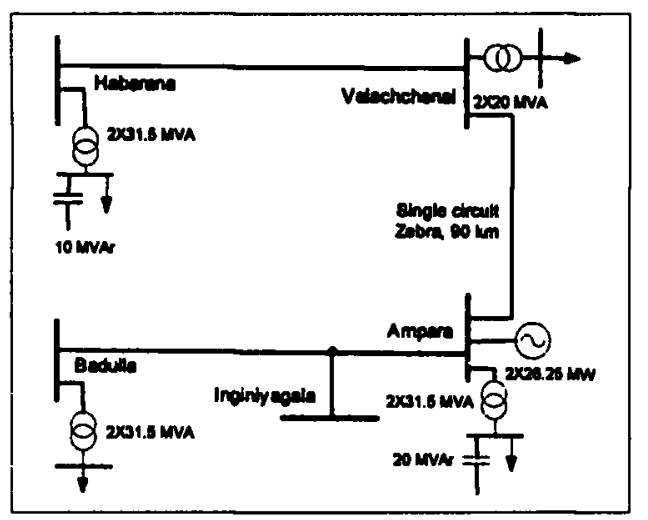

Figure 6: Initial arrangement for solution 2 (b)

Required reactive power is obtained by both generators and a capacitor bank. Remedial action schedule is given in appendix, table 7.

\subsubsection{Solution 3}

Proposal 6 is to proceed with double circuit from Habarana to Valachchenai as shown in figure 7. Remedial action schedule is given in appendix, table 8.

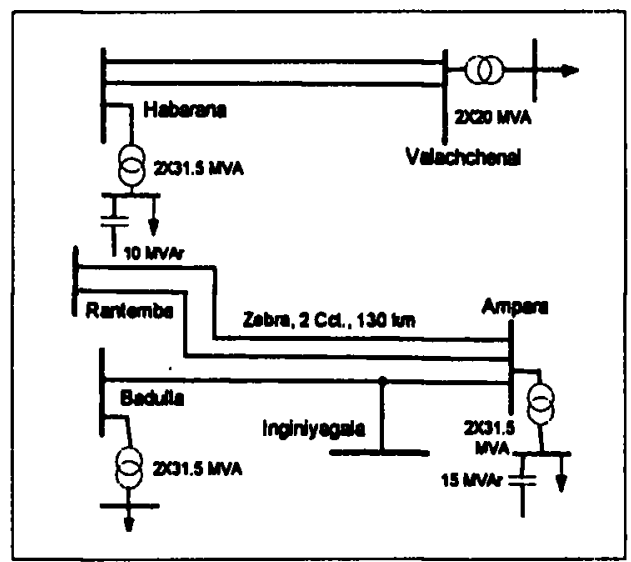

Figure 7: Initial arrangement for solution 3

\subsubsection{Solution 4}

The system configuration for solution 3 is being initially launched and an active power injection carried out to operate Ampara as a "PV bus". Remedial action schedule is given in appendix, table 9.

\subsubsection{Solution 5}

The initial system configuration is same as in solution 2 (a). Rantembe-Ampara transmission line is being connected to the system at the appropriate time. Remedial action schedule is given in appendix table 10.

\subsubsection{Solution 6 (additional study)}

The initial system configuration is as in solution 2 (b) but always maintained the bus voltage at Ampara, more than $125.4 \mathrm{kV}$ ( 0.95 p.u.) all the time. Required reactive power is obtained by both generators and capacitor banks. Remedial action schedule is given in appendix, table 11.

\section{Financial Analysis of Options}

Since the study has unearthed six possible solutions which are technically feasible, concern has been given to the technon economic study of each alternative solution for the sake of optimising one of those for the proposed period of 10 years. In the financial analysis, first step was to identify the required substation modifications, construction and upgrading of 
existing switchgears. Thereafter the cost of each modification has been summed up in yearly basis. By using 10\% "Discount rate", all the costs have been taken into the present (i.e. the year 2005). As most of the present day project evaluations are based on C.B.A. (Cost Benefit Analysis), concern has been given to the Cost Benefit analysis of each of the alternative solutions. As study period is restricted to only 10 years ahead (will be about 8 or 7 years after allowing two or three years for the initial constructions), a comparison with the total life time of a project ( $>20$ years) will prove that most of the benefits are left uncovered even though almost all costs happen to be within the time frame.

\subsection{Cost calculations}

In order to minimise the complexity, all implementations are categorised into three sections such as generation, transmission and substation modifications.

\subsubsection{Generation}

Finding out the required active power injection for technical analysis, was not restricted to a particular mode of generation. But for economical analysis a specific type of plant had to be chosen. To fulfil the requirement, preference was given to several types of candidate plants designated for Sri Lanka power system by the C.E.B. During the preliminary screening it was found that we would have to use either diesel power plants or gas turbines. But in the course of final screening gas turbines has to be selected even though the large burden of annual running costs is inherent. In N-1 contingency, loss of a generator unit is taken as 26.25 MW and also due to the following two reasons and lack of other options, made way to depend on gas turbines. Firstly, the W.A.S.P. optimisation gives two types of gas turbines as future generation additions consisting of $75 \mathrm{MW}$ and $105 \mathrm{MW}$ in capacity. Secondly, it is now becoming a national policy not to use any diesel generation plants as future candidate plants.

Costs calculation mainly consists of the following factors.

- Capital investment cost

- Operational \& maintenance cost (fixed component)
- Operational \& maintenance cost (variable component)

- Fuel cost

Construction period is estimated as two years as a matter of urgency and hence such projects will starts to operate from year 2007 onwards. A price hike of $5 \%$ per year is considered for Auto diesel. The total investment period of two years is divided into factors of 0.4 and 0.6 respectively and each of the extension of generation is taken as $80 \%$ of the initial investment.

\subsubsection{Reducing the generation costs}

Several possibilities for reducing generation cost (i.e. massive running cost) are summarised below.

- Changing the type of plant; if the plant is of large scale combine cycle or coal then the running costs are drastically reduced, compared to their capacities. And also there is the possibility of erecting such a plant by using "Oluvil harbour". Also it might be required to interconnect Valachchenain Ampara and ValachchenaiñTrincomalee grid substations.

- It was found that there is a possibility of making a power station of around $25 \tilde{n} 30$ MW by using the garbage and waste matter found in the area. Also it seems to be a fine solution to make use of piles of paddy husks, one of the increasing environmental problems of the area. Also it increases, infrastructure development, employment opportunities, and hence a greater uplifting of the social status.

- It is worthwhile to find out the possibility of changing the type of fuel from auto diesel to furnace oil which is cheaper.

\subsubsection{Transmission}

The costs of transmission line projects consist mainly of two components.

- Cost of erecting the transmission line

- Cost of $132 \mathrm{kV}$ line bays

Apart from the topics given above, the total cost may subject to be increase with the addition of $O \& M$ cost of transmission lines. Typical construction period is estimated as 3 years and the total investment is divided into factors $\mathbf{0 . 2}$, 0.7 and 0.1 respectively for successive years. 


\subsubsection{Cost of required substation modifications}

Under this category the cost of individual equipments and other augmentations which didnit cover up under above two were being considered.

\subsection{Benefit analysis}

It is somewhat a very difficult task tó carryout a benefit analysis when compared with each individual project for a limited period of time. Therefore a creative and innovative methodology has been applied for finding benefits in comparison with the present system rather than comparing the benefits in-between the types of proposals. The benefit analysis comprises three main components.

- Cost of E.N.S. (Energy Not Served)

- Possibility of catering the future load growth

- Loss benefits

To find out most of the above mentioned cost components it is necessary to know the behaviour pattern of load consumption (i.e. load curves of grid substations). The typical load curve at present for Ampara is given in figure 8.

\subsubsection{Cost of E.N.S.}

The Ampara G.S. is presently experiencing a voltage droop problem. According to the voltage criteria, minimum permissible voltage of $132 \mathrm{kV}$ bus at Ampara should be $118.8 \mathrm{kV}$, although in reality it drops to around $107 \mathrm{kV}$ at night peak which is totally unacceptable. Responding to the situation the maximum load corresponding to $118.8 \mathrm{kV}$ at Ampara G.S. was checked and found to be around 44.5 MW. So the decision was taken to shed the excessive load which is already connected to the G.S. and count that energy under E.N.S. According to the violation of firm substation capacity the maximum permissible load at present from Ampara G.S. is about $40 \mathrm{MW}$. But the marginal limit is taken as $44.5 \mathrm{MW}$, which is the corresponding maximum loading at Ampara to maintain $118.8 \mathrm{kV}$ at night peak. The energy covered under energy shed is taken as serving of E.N.S. which is $8.287 \mathrm{GWh}$

\subsubsection{Catering the future load growth}

If we are able to meet the future load growth as we are predicting today, we will be earning more money from our new consumers. As most of the consumers pertaining to the Eastern area are domestic consumers, it is preferable to use nominal domestic charge rates to find out the revenue from new consumers. Due to the rapid contribution of thermal power to Sri Lanka power system along with the ever increasing fuel prices; it is somewhat justifiable if the rates are increased by about $8-10 \%$ annually. But since we are expecting major generation projects such as coal power station at Puttalam, and another at Upper Kotmale there will definitely be a considerable price reduction.

\section{Dally load curve at Ampara}

Load factor 0.53

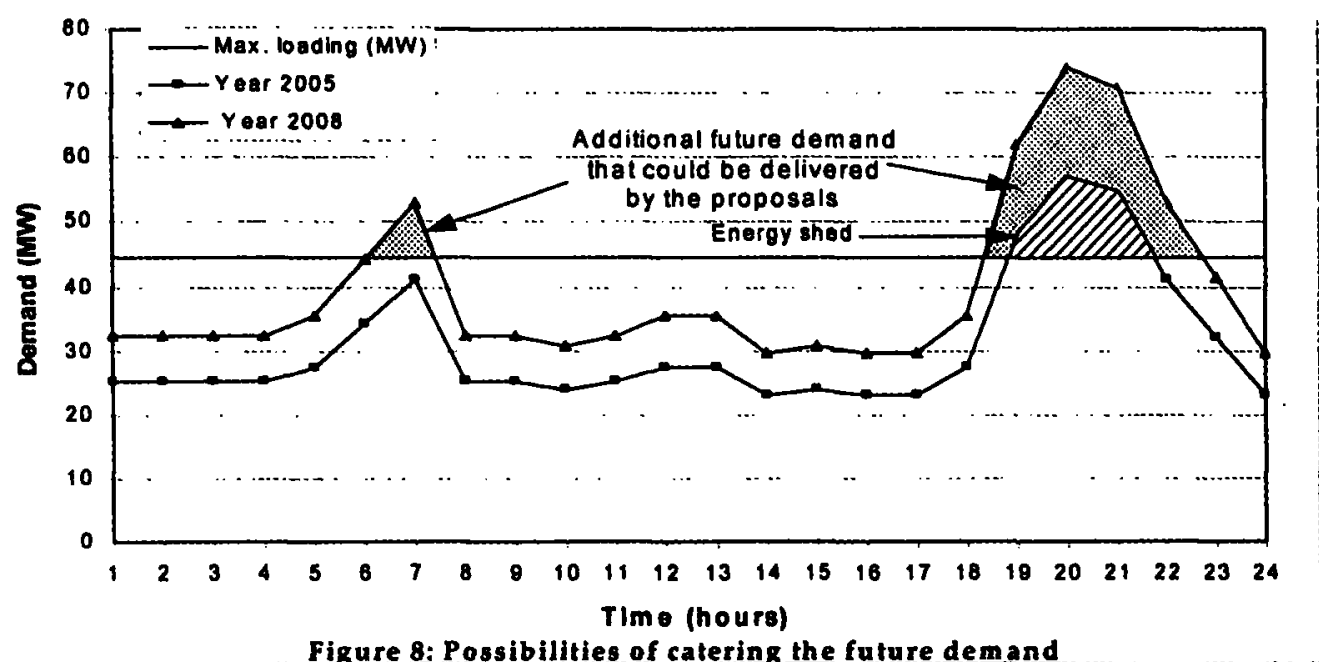


Finding out of losses that occur in each of the transmission lines of the area for each solution for several years is not an easy task. But a genuine effort was taken to make an account under this topic in which it seems that generator option is more advantages when compared with the transmission option. All loss benefit analysis is being obtained in comparison to the present day losses. Area loss is estimated as $41.3 \mathrm{MWh}$ per day and the loss factor is assumed to be around $0.3-0.35$.

Cost benefit analysis for each of the projects during the total study period are tabulated in table 3.

\section{Conclusion}

As clearly visualise from the gist of contents regarding this study, the solutions 1,3 and 4 will only be able to cover up the expenses, incurred for each as found during the study period. All other options seem to be uneconomical because of their massive expenses. Hence, the final conclusion is to go ahead with solution 3 , as it is the best economically viable solution in hand to strengthen the Eastern area power system. As clearly pointed out from the figures given above one could easily understand how much loss is incurred in delaying without a fitting solution. As not in the case of social welfare projects like rural area electrification, this project could earn its expenses within a short period of time. As it is revealed during this study, the next major construction which is most appropriate would definitely be a power station located with in this area. But the exact place \& year for commencing and its type/size may subjected to be changed in its detailed design stage. Also by the end of year 2014, Ampara and Padirippu grid substations are most likely to reach their firm substation capacity requesting the necessity of constructing a new grid substation at or near Batticaloa to meet that increasing demand. It will be necessary to interconnect Valachchenai and Ampara grid substations at that time.

\section{References}

1. Long term Generation Expansion Plan 2005, Generation planning \& Design branch, CEB

2. Long term transmission development study 2004 2013, Generation planning \& Design branch, CEB

3. Lalith A. Samaliarachchi., \& Tilak Siyambalapitiya., Power System Plnmning (ECX 6332), The Open University of Sri Lanka

4. Master plan study on the development of the porver generation and transmission system in Sri Lankn, July 2005, Chubu Electric Power Co. \& Nomura Research Institute, Ltd.

5. Master plan study on Sri Lankn powver system, February 2006 by JICA

\section{Acknowledgements}

The authors are thankful to Prof. H. Sriyananda, Prof. J. Rohan Lucas and Dr. K.A.C. Udayakumar for their valuable support and also Mr. Gemunu Abayasekara D.G.M. (T\&GP), Ceylon Electricity Board for making allowance to obtained the required data.

Table 3: Financial data on each of the alternative solutions

\begin{tabular}{|l|c|c|c|c|c|}
\hline Solution & Costs (Rs. M) & $\begin{array}{c}\text { Benefits } \\
\text { (Rs. M) }\end{array}$ & $\begin{array}{c}\text { Benefit - costs } \\
\text { (Rs. M) }\end{array}$ & Recovery & $\begin{array}{c}\text { Benefiy } \\
\text { cost ratio }\end{array}$ \\
\hline 1 & 2830.1 & 10550.3 & 7720.2 & Yes & 3.730 \\
2 (a) & 51496.0 & 12495.0 & -39001.0 & No & 0.243 \\
2 (b) & 45017.8 & 12470.9 & -32546.9 & No & 0.277 \\
3 & 2817.6 & 10668.7 & 7851.1 & Yes & 3.786 \\
4 & 6903.8 & 10735.8 & 3832.0 & Yes & 1.555 \\
5 & 41919.2 & 12831.7 & -29087.5 & No & 0.306 \\
6 & 41404.5 & 12416.1 & -28988.4 & No & 0.300 \\
\hline
\end{tabular}


Table 4: Proposals considered for analytical stage 1

\begin{tabular}{|c|c|c|}
\hline & Proposal & Comments on results \\
\hline 1 & $\begin{array}{l}\text { Install an approximately } 130 \mathrm{~km}, 132 \mathrm{kV} \\
\text { overhead double circuit line using } \\
\text { "ZEBRA" conductors between Rantembe } \\
\text { and Ampara. Bus voltage is boosted up } \\
\text { with reactive power injection by } \\
\text { installing a capacitor bank.) }\end{array}$ & $\begin{array}{l}\text { Found it out as a potential solution to the voltage drop } \\
\text { problem and for thermal overloading, not only for the } \\
\text { present but also for few years ahead without remedial } \\
\text { action and also it increases the reliability of continuous } \\
\text { supply without failure to Ampara grid substation. The } \\
\text { benefactors are those consumers covered up under } \\
\text { Ampara Grid Substation. }\end{array}$ \\
\hline 2 & $\begin{array}{l}\text { The bus voltage at Ampara is to be } \\
\text { normalised only by injection of reactive } \\
\text { power to the } 33 \mathrm{kV} \text { bus bar side. }\end{array}$ & $\begin{array}{l}\text { This could be considered as a potential solution to } \\
\text { overcome the voltage problem. But it doesn't give any } \\
\text { relief either for thermal overloading or reliability } \\
\text { problem. In course of time more capacitors are } \\
\text { required, to maintain the bus voltages within the } \\
\text { standard level. Here also the benefactors are those } \\
\text { consumers covered up under Ampara Grid Substation }\end{array}$ \\
\hline 3 & $\begin{array}{l}\text { Install an approximately } 90 \mathrm{~km}, 132 \mathrm{kV} \\
\text { overhead single circuit line using } \\
\text { "ZEBRA" conductors between Ampara } \\
\text { and Valachchenai. Bus voltage is } \\
\text { corrected with reactive power injection } \\
\text { by installing a capacitor bank. }\end{array}$ & $\begin{array}{l}\text { Another potential solution to the voltage drop problem } \\
\text { and also for } 132 \mathrm{kV} \text { transmission overloading to a } \\
\text { lesser extent. It increases the reliability of both } \\
\text { Valachchenai-Habarana and Badulla-Ampara via } \\
\text { inginiyagala feeders. Here the benefactors are } \\
\text { consumers covered up under Ampara and } \\
\text { Valachchenai Grid Substations. }\end{array}$ \\
\hline 4 & \begin{tabular}{|l|}
$\begin{array}{l}\text { Install a double circuit overhead line } \\
\text { between Valachchenai and Ampara } \\
\text { using "ZEBRA" conductors. }\end{array}$ \\
\end{tabular} & $\begin{array}{l}\text { The solution could be categorised as a strengthened } \\
\text { form of proposal } 3 \text { which improves the reliability of } \\
\text { transmitting power to the areas influenced by it. }\end{array}$ \\
\hline 5 & $\begin{array}{l}\text { This connects Badulla-Ampara with a } \\
\text { new "ZEBRA" single circuit line and the } \\
\text { length of the line is taken as same as the } \\
\text { existing transmission line length. }\end{array}$ & $\begin{array}{l}\text { Could be identified as a solution for both voltage drop } \\
\text { and thermal overloading problems and increases the } \\
\text { reliability of Badulla-Ampara transmission. } \\
\text { Benefactors are consumers covered up under Ampara } \\
\text { grid substation. }\end{array}$ \\
\hline 6 & \begin{tabular}{|l|} 
Connect Rantembe-Ampara with a \\
double circuit overhead 132 $\mathrm{kV}$ line \\
using "Zebra" conductors without \\
decommissioning the existing lines.
\end{tabular} & $\begin{array}{l}\text { It is a more strengthened form of solution than the first } \\
\text { proposal. }\end{array}$ \\
\hline 7 & $\begin{array}{l}\text { Install a single circuit line using } \\
\text { "ZEBRA" conductors between } \\
\text { Valachchenai and Ampara. But here the } \\
\text { capacitor bank is done away with; } \\
\text { instead the nominal bus voltage is } \\
\text { maintained by injecting active power to } \\
\text { the } 132 \mathrm{kV} \text { by installing a power plant. }\end{array}$ & $\begin{array}{l}\text { It also is a better solution to the voltage problem. The } \\
\text { time of } 132 \mathrm{kV} \text { overloading depends on the capacity of } \\
\text { the power station. It could be used economically with } \\
\text { the existing transmission system. }\end{array}$ \\
\hline 8 & $\begin{array}{l}\text { This connects Ampara - Valachchenai } \\
\text { with a double circuit Zebra transmission } \\
\text { line and nominal bus voltage is } \\
\text { maintained by injecting active power by } \\
\text { installing a power plant. }\end{array}$ & $\begin{array}{l}\text { It could be taken as a far better solution than the } 7^{\text {th }} \\
\text { proposal. But the performance at daytime for both } \\
\text { hydro and thermal maximum conditions seems to be } \\
\text { poor. }\end{array}$ \\
\hline 9 & $\begin{array}{l}\text { This connects Rantembe-Ampara with a } \\
\text { double circuit overhead transmission } \\
\text { line. But here instead of a capacitor bank, } \\
\text { a power plant is being replaced. }\end{array}$ & $\begin{array}{l}\text { Cannot be considered as a timely solution because the } \\
\text { connection of lines itself solves the problem to a great } \\
\text { extent and a power plant is not an essential need by the } \\
\text { year } 2005 \text {. }\end{array}$ \\
\hline 10 & $\begin{array}{l}\text { All the existing transmission lines are } \\
\text { kept as usual. Ampara experiences the } \\
\text { coming up of a new power station. }\end{array}$ & $\begin{array}{l}\text { Although the voltage and thermal overloading } \\
\text { problems could be averted, this proposal cannot be } \\
\text { regarded as a fine solution since the failure of existing } \\
\text { feeder, Badulla-Ampara will result in isolating } \\
\text { Ampara (islanding) from the rest of the system }\end{array}$ \\
\hline
\end{tabular}


Table 5: Summary of solution 1

\begin{tabular}{|c|c|c|c|}
\hline \multirow{2}{*}{ Year } & \multicolumn{2}{|r|}{ Remarka } & \multirow{2}{*}{ Remedial action } \\
\hline & Normal & Contingency & \\
\hline \multirow{2}{*}{2005} & - & $\begin{array}{c}\text { Haharana - Valachehenai } \\
\text { Unacceptable low volage } \\
\text { levels at Ampara \& } \\
\text { Valachchenai }\end{array}$ & $\begin{array}{c}\text { Install a capacitor bank of } 10 \\
\text { MVAr at Valachchenai }\end{array}$ \\
\hline & \multicolumn{2}{|c|}{$\begin{array}{l}\text { Violation of firm substation capacily } \\
\text { at Valachchenal, Ampara \& Badulla }\end{array}$} & $\begin{array}{l}\text { Install the 3rd transformer. Hence, } \\
\text { Valachchenaj (Bx10 MVA) } \\
\text { Ampara ( } 3 \times 31.5 \text { MVA) \& } \\
\text { Badulla ( } 3 \times 31.5 \text { MVA) }\end{array}$ \\
\hline 2006 & \multicolumn{2}{|c|}{$\begin{array}{c}\text { Violation of firm substation capacity } \\
\text { at Habarana }\end{array}$} & $\begin{array}{c}\text { Install the } 3 \text { ro trassformer. Hence } \\
\text { 3×31.5 MVA. }\end{array}$ \\
\hline 2000 & - & $\begin{array}{c}\text { Habarana - Valachchenai } \\
\begin{array}{c}\text { Unacceptable low voltage } \\
\text { at Valachehenai }\end{array} \\
\text { Overloading } \\
\text { Badulla - Inginiya, feeder }\end{array}$ & $\begin{array}{l}\text { Commission the Rantembe - } \\
\text { Ampara double circuit line }\end{array}$ \\
\hline 2008 & - & $=$ & $\cdot$ \\
\hline 2009 & \multicolumn{2}{|c|}{$\begin{array}{l}\text { Violation of firm substation capacity } \\
\text { al Polonnaruwa \& Madagama }\end{array}$} & $\begin{array}{l}\text { Install the } 2^{\text {ma }} \text { transformer. Hence } \\
\text { Polonnanuwa (2x31.5 MVA) \& } \\
\text { Madagama (2x31.5 MVA) }\end{array}$ \\
\hline 2010 & - & - & - \\
\hline 2011 & - & - & - \\
\hline 2012 & - & - & . \\
\hline \multirow[b]{2}{*}{2013} & \multirow[b]{2}{*}{ • } & Habarana - Polonnaruwa & \multirow{2}{*}{$\begin{array}{l}\text { Install a capactlor bank of } \\
\text { 5MVA at Polonnaruwa }\end{array}$} \\
\hline & & $\begin{array}{c}\text { Unacceptable low voliage } \\
\text { at Polonnaruwa }\end{array}$ & \\
\hline \multirow{3}{*}{2014} & \multirow[b]{2}{*}{ 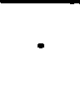 } & Habarana - Polonnaruwa & \multirow[b]{2}{*}{ Install 5MVA at Polonnaruwa } \\
\hline & & $\begin{array}{c}\text { Unacceptable low voltage } \\
\text { at Polonnaruwa }\end{array}$ & \\
\hline & \multicolumn{2}{|c|}{$\begin{array}{l}\text { Violation of firm substation capacily } \\
\text { at Padirippu }\end{array}$} & $\begin{array}{l}\text { Instal the } 3^{\text {rd }} \text { transformer. Hence } \\
\text { Pad ivippu (3x31.5 MVA) }\end{array}$ \\
\hline
\end{tabular}

\begin{tabular}{|c|c|c|c|}
\hline \multirow{2}{*}{ Year } & \multicolumn{2}{|r|}{ Remarks } & \multirow{2}{*}{ Remedial action } \\
\hline & Normal & Contingency & \\
\hline \multirow[b]{3}{*}{2005} & \multirow[t]{2}{*}{ - } & Loss of a generator & $\begin{array}{l}\text { Install a capacitor bank of } 20 \\
\text { MVAr at Ampara } 33 \mathrm{kV} \text { load side }\end{array}$ \\
\hline & & Reached Q $Q_{\max }$ at Ampara & Install 5 MVAr al Poonnaruwa \\
\hline & \multicolumn{2}{|c|}{$\begin{array}{l}\text { Violation of firm substation capacity } \\
\text { at Valachchenai, Ampara \& Badulla }\end{array}$} & $\begin{array}{c}\text { Install the } 3^{\text {nd }} \text { transformer. Hence, } \\
\text { Valachchenai ( } 3 \times 10 \mathrm{MVA}) \text {, } \\
\text { Ampara ( } 3 \times 31.5 \mathrm{MVA}) \& \\
\text { Badulla ( } 3 \times 31.5 \mathrm{MVA})\end{array}$ \\
\hline 2006 & \multicolumn{2}{|c|}{$\begin{array}{l}\text { Viohation of firm substation capacity } \\
\text { at Habarana }\end{array}$} & $\begin{array}{c}\text { Install the } 3^{\text {rd }} \text { transformer. Hence } \\
\text { 3x31.5 MVA. }\end{array}$ \\
\hline \multirow[b]{2}{*}{2007} & \multirow[b]{2}{*}{ - } & Loss of a generatior & \multirow{2}{*}{$\begin{array}{l}\text { Install a capacitor of } 5 \text { MVAr at } \\
\qquad 33 \mathrm{kV} \text { load side }\end{array}$} \\
\hline & & Reached Qmon at Ampara & \\
\hline 2008 & - & $\begin{array}{l}\text { Loss of a generator } \\
\text { Reached O at Ampara }\end{array}$ & Install the $3^{\mathrm{rd}}$ generator \\
\hline 2009 & \multicolumn{2}{|c|}{$\begin{array}{l}\text { Violation of firm substation capacity } \\
\text { at Polonraruwa \& Madagama }\end{array}$} & 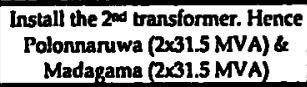 \\
\hline 2010 & - & - & - \\
\hline 2011 & - & $\cdot$ & - \\
\hline 2012 & - & $\begin{array}{l}\text { Loss of a generator } \\
\text { Reached } Q_{\operatorname{mar}} \text { al Ampara }\end{array}$ & Install the $4^{\text {th }}$ generator \\
\hline 2013 & $\cdot$ & - & - \\
\hline \multirow{3}{*}{2014} & \multirow[b]{2}{*}{ - } & Habarana - Polonnaruwa & \multirow[b]{2}{*}{$\begin{array}{c}\text { Install } 10 \text { MVAr at Polonnaruwa } \\
\text { \& } 5 \text { MVAr at Padirippu }\end{array}$} \\
\hline & & $\begin{array}{c}\text { Un acceptable low voltage } \\
\text { at Polonnaruwa }\end{array}$ & \\
\hline & \multicolumn{2}{|c|}{$\begin{array}{c}\text { Violation of firm substation capacity } \\
\text { at Padirippu }\end{array}$} & $\begin{array}{c}\text { Install the } 3^{\text {rod }} \text { transformer. Hence } \\
\text { Pad irippu (3x31.5 MVA) }\end{array}$ \\
\hline
\end{tabular}

Table 6: Summary of solution 2 (case a)

\begin{tabular}{|c|c|c|c|}
\hline \multirow{2}{*}{ Year } & \multicolumn{2}{|r|}{ Remarks } & \multirow{2}{*}{ Remedial action } \\
\hline & Normal & Contingency & \\
\hline \multirow[b]{3}{*}{2005} & & Loss of a generalor & Install the $3^{\text {Nd }}$ Rencenlor \\
\hline & & Reached $Q_{m, n}$ at Ampara & $\begin{array}{l}\text { Install a capacitor of 5MVAr at } \\
\text { Valachchenal }\end{array}$ \\
\hline & \multicolumn{2}{|c|}{$\begin{array}{l}\text { Vlolation of firm substation capacity } \\
\text { at Valachchenai, Ampara \& Badulla }\end{array}$} & $\begin{array}{l}\text { Install the } 3 \text { transformer. Hence, } \\
\text { Valachehenai ( } 3 \times 10 \mathrm{MVA}) \text {. } \\
\text { Ampara }(3 \times 31.5 \mathrm{MVA}) \mathrm{Q} \\
\text { Badulla ( }(3 \times 31.5 \mathrm{MVA})\end{array}$ \\
\hline 2006 & \multicolumn{2}{|c|}{$\begin{array}{l}\text { Violation of firm substation capacity } \\
\text { at Habarand }\end{array}$} & $\begin{array}{c}\text { Install the } 3 \text { ro Iransformer. Henee } \\
3 \times 31.5 \text { MVA. }\end{array}$ \\
\hline 2007 & - & - & - \\
\hline 208 & - & - & - \\
\hline \multirow[b]{2}{*}{2009} & - & $\begin{array}{l}\text { Loss of a generator } \\
\text { Reached Q } \\
\text { Rer al Ampara }\end{array}$ & Install the $4^{\text {m }}$ generator \\
\hline & \multicolumn{2}{|c|}{$\begin{array}{l}\text { Violation of firm substation capacily } \\
\text { at Polonnaruwa \& Madagama }\end{array}$} & 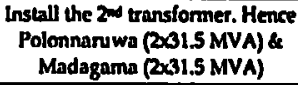 \\
\hline 2010 & $\cdot$ & $\cdot$ & - \\
\hline ni & - & - & - \\
\hline \multirow{2}{*}{2012} & \multirow{2}{*}{ - } & Loss of a gencrator & \multirow{2}{*}{$\begin{array}{l}5 \text { MVAr capacitor at } 33 \mathrm{kV} \text { losd } \\
\text { slue }\end{array}$} \\
\hline & & Reached Qma at Ampara & \\
\hline & & Loss of a generator & \multirow{2}{*}{$\begin{array}{c}\text { Install a capacitor bank of is } \\
\text { MVAr at Ampara } 33 \mathrm{kV} \text { lond side }\end{array}$} \\
\hline & & Reached $Q_{\text {max }}$ al Ampara & \\
\hline \multirow{3}{*}{7} & & Habarana - Polonnaruwa & \multirow{2}{*}{$\begin{array}{c}\text { Install 10 MVAr at Polonnaruwa } \\
\text { \& } 10 \mathrm{MVAr} \text { at Padirippu }\end{array}$} \\
\hline & & $\begin{array}{l}\text { Unacceptable low voltage } \\
\text { at Polonnaruwa }\end{array}$ & \\
\hline & \multicolumn{2}{|c|}{$\begin{array}{l}\text { Violation of firm substation capacity } \\
\text { at Padirippu }\end{array}$} & 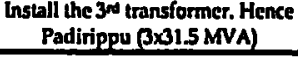 \\
\hline
\end{tabular}

Table 8: Summary of solution 3

\begin{tabular}{|c|c|c|c|}
\hline \multirow{2}{*}{ Year } & \multicolumn{2}{|r|}{ Remarks } & \multirow[t]{2}{*}{ Remedial action } \\
\hline & Normal & Contingensy & \\
\hline \multirow[b]{2}{*}{2005} & \multirow{2}{*}{\multicolumn{2}{|c|}{$\begin{array}{l}\text { Violation of firm substation capacity } \\
\text { at Valachchenal, Ampara \& Badulla }\end{array}$}} & $\begin{array}{l}\text { Install a capacitor bank of } 5 \\
\text { MVAr ai Valachchenai }\end{array}$ \\
\hline & & & 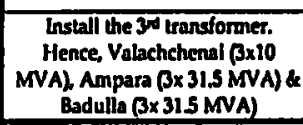 \\
\hline \multirow{2}{*}{ Year } & & Remarks & \multirow{2}{*}{ Rennedial action } \\
\hline & Normal & Contingensy & \\
\hline 2006 & \multicolumn{2}{|c|}{$\begin{array}{c}\text { Violation of firm substation capacity } \\
\text { al Habarana }\end{array}$} & $\begin{array}{c}\text { Install the } 3 \text { s trunsformer. Hence } \\
3 \times 31.5 \mathrm{MVA} \text {. }\end{array}$ \\
\hline 2007 & • & - & - \\
\hline 2008 & - & - & $\cdot$ \\
\hline 2009 & \multicolumn{2}{|c|}{$\begin{array}{l}\text { Violation of firm substation capacity } \\
\text { at Polonnaruwa \& Madagama }\end{array}$} & 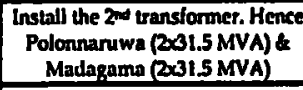 \\
\hline 2010 & - & $\cdot$ & $\cdot$ \\
\hline 2001 & - & - & - \\
\hline 2012 & - & - & - \\
\hline 2013 & $\bullet$ & - & - \\
\hline \multirow{3}{*}{2014} & \multirow[b]{2}{*}{ - } & $\begin{array}{c}\text { Rantembe - Madagama } \\
\text { 1eet. }\end{array}$ & \multirow{2}{*}{ Install 5MVAr at Padirlppu } \\
\hline & & $\begin{array}{c}\text { Unacceptable low voltage } \\
\text { at Padirippu }\end{array}$ & \\
\hline & \multicolumn{2}{|c|}{$\begin{array}{c}\text { Violation of firm substrtion capacify } \\
\text { al Padirippu }\end{array}$} & $\begin{array}{l}\text { Instal] the } 3^{\text {did }} \text { transformer. Hence } \\
\text { Padirippu }(3 \times 31.5 \mathrm{MVA})\end{array}$ \\
\hline
\end{tabular}




\begin{tabular}{|c|c|c|c|}
\hline \multirow{2}{*}{ Year } & \multicolumn{2}{|r|}{ Remarks } & \multirow{2}{*}{ Remedial action } \\
\hline & Norma! & Conlingency & \\
\hline \multirow[b]{2}{*}{2005} & \multirow{2}{*}{\multicolumn{2}{|c|}{$\begin{array}{l}\text { Violation of firm substation capacity } \\
\text { at Valachehenai, Ampara \& Badulla }\end{array}$}} & $\begin{array}{l}\text { Install a capacitor bank of } 5 \\
\text { MNAr at Valachchenai }\end{array}$ \\
\hline & & & $\begin{array}{c}\text { Install the 3ru transformer. } \\
\text { Hence, Valachchenai ( } 3 \times 10 \\
\text { MiVA), Ampara ( } 3 \times 31.5 \mathrm{MVA} \text { ) \& } \\
\text { Badulla ( } 3 \times 31.5 \mathrm{MVA})\end{array}$ \\
\hline \multirow{2}{*}{ Year } & & Remarks & \multirow{2}{*}{ Remedial action } \\
\hline & Normal & Contingency & \\
\hline 2006 & \multicolumn{2}{|c|}{$\begin{array}{c}\text { Violation of tirm substation rapacity } \\
\text { at Habarnna }\end{array}$} & $\begin{array}{c}\text { Install the } 3 \text { ra transformer. Ilence } \\
3 \times 31.5 \mathrm{NVA} \text {. }\end{array}$ \\
\hline 2007 & - & - & - \\
\hline 2008 & - & - & - \\
\hline 2009 & \multicolumn{2}{|c|}{$\begin{array}{l}\text { Violation of firm substation capacity } \\
\text { at Polonnaruwa \& Madagama }\end{array}$} & $\begin{array}{c}\text { Install the } 2^{\text {nd }} \text { transformer. I fence } \\
\text { Polonnaniwa }(2 \times 31.5 \mathrm{MVA}) \text { ) } \\
\text { Mlathagama }(2 \times 31.5 \mathrm{MVA})\end{array}$ \\
\hline 2010 & . & - & - \\
\hline 2011 & $\cdot$ & - & - \\
\hline 2012 & $\cdot$ & - & - \\
\hline 2013 & - & - & - \\
\hline \multirow{3}{*}{2014} & & Rantembe - Ampara 1ect. & \multirow{2}{*}{$\begin{array}{c}\text { Install a } 52.5 \text { MVA generator } \\
\text { Install a capacitor of } 5 \text { MVAr at } \\
\text { padinppu } 33 \mathrm{kV} \text { bus }\end{array}$} \\
\hline & & $\begin{array}{c}\text { Unacceptable low voltage } \\
\text { at Padirippu }\end{array}$ & \\
\hline & \multicolumn{2}{|c|}{$\begin{array}{c}\text { Violation of firm substation capacity } \\
\text { at Padirippu }\end{array}$} & $\begin{array}{l}\text { Install the } 3^{\text {ro transformer. Hence }} \\
\text { Padirippu (3x31.5 MVA) }\end{array}$ \\
\hline
\end{tabular}

\begin{tabular}{|c|c|c|c|}
\hline \multirow{2}{*}{ Year } & \multicolumn{2}{|r|}{ Remarks } & \multirow{2}{*}{ Remedial action } \\
\hline & Normal & Contingengy & \\
\hline \multirow[b]{3}{*}{2005} & \multirow[t]{2}{*}{$\cdot$} & Loss of a generatios & $\begin{array}{l}\text { Install a capacitor bank of } 5 \\
\text { MVAr at Valachchenai }\end{array}$ \\
\hline & & Reached $Q_{m a}$ al Ampara & Install the 3rd generator \\
\hline & \multicolumn{2}{|c|}{$\begin{array}{l}\text { Violation of firm substation capacity } \\
\text { at Valachehenai, Ampara \& Badulla }\end{array}$} & $\begin{array}{l}\text { Install the } 3^{\text {NA }} \text { transformer. } \\
\text { Hence, Valachchenai ( } 3 \times 10 \\
\text { MVA), Ampara ( } 3 \times 31.5 \text { MVA) \& } \\
\text { Badulla ( } 3 \times 31.5 \text { MVA) }\end{array}$ \\
\hline 2006 & \multicolumn{2}{|c|}{$\begin{array}{c}\text { Violation of firm substation capacity } \\
\text { at Habarana }\end{array}$} & $\begin{array}{l}\text { Install the } 3 \text { ro transformer. Hence } \\
\qquad 3 \times 31.5 \mathrm{MVA} \text {. }\end{array}$ \\
\hline 2007 & $\cdot$ & - & - \\
\hline 2008 & - & - & - \\
\hline \multirow[b]{3}{*}{2009} & \multirow[b]{2}{*}{ - } & Loss of a generalor & \multirow{2}{*}{$\begin{array}{l}\text { Commission the Rantembe - } \\
\text { Ampara feeders }\end{array}$} \\
\hline & & Reached $Q_{\operatorname{man}}$ at Ampara & \\
\hline & \multicolumn{2}{|c|}{$\begin{array}{l}\text { Violation of firm substation capacity } \\
\text { ai Polonnaruwa \& Madagama }\end{array}$} & $\begin{array}{l}\text { Install the } 2^{\text {md }} \text { transformer. Hence } \\
\text { Polonnaruwa }(2 \times 31.5 \text { HVA } \& \\
\text { Madagama }(2 \times 31.5 \text { hVA }\end{array}$ \\
\hline 2010 & - & $\cdot$ & - \\
\hline \multirow{2}{*}{ Year } & & Remarks & \multirow{2}{*}{ Remedial action } \\
\hline & Normal & Conlingency & \\
\hline 2011 & - & - & - \\
\hline 2012 & - & $\cdot$ & - \\
\hline 2013 & - & $\cdot$ & $\cdot$ \\
\hline 2014 & \multicolumn{2}{|c|}{$\begin{array}{c}\text { Viobtion of firm substation capacity } \\
\text { at Padirippu }\end{array}$} & $\begin{array}{l}\text { Install the } 3^{\mathrm{m}} \text { transformix. Hence } \\
\text { Padirippu (3x31,5 MVA) }\end{array}$ \\
\hline
\end{tabular}

\begin{tabular}{|c|c|c|c|}
\hline \multirow{2}{*}{ Year } & \multicolumn{2}{|r|}{ Remarks } & \multirow{2}{*}{ Remedial action } \\
\hline & Normal & Contingency & \\
\hline \multirow[b]{2}{*}{2005} & \multirow{2}{*}{\multicolumn{2}{|c|}{$\begin{array}{l}\text { Violation ol firm substation capacity } \\
\text { at Valachchenai, Ampara \& Badulla }\end{array}$}} & $\begin{array}{l}\text { Install a capacilor bank of } 5 \\
\text { MVAr at Valachchenai }\end{array}$ \\
\hline & & & $\begin{array}{l}\text { Install the 3rd transformer. } \\
\text { Hence, Valachchenai ( } 3 \times 10 \\
\text { MVA), Ampara ( } 3 \times 31.5 \text { MVA) } \\
\text { Badulla ( } 3 \times 31.5 \text {.MVA) }\end{array}$ \\
\hline $200 \%$ & \multicolumn{2}{|c|}{$\begin{array}{c}\text { Violation of firm substation capacity } \\
\text { at Habarana }\end{array}$} & $\begin{array}{l}\text { Install the } 3^{\text {rd }} \text { transformer. Hence } \\
3 \times 31.5 \text { MVA. }\end{array}$ \\
\hline 2007 & - & - & - \\
\hline 2008 & - & $\begin{array}{l}\text { Loss of a generator } \\
\text { Reached } Q_{\operatorname{mar}} \text { at Ampara }\end{array}$ & $\begin{array}{c}\text { Install a capacitor of } 5 \mathrm{MVAr} \text { at } \\
\text { Ampara } 33 \mathrm{kV} \text { load side }\end{array}$ \\
\hline \multirow[b]{2}{*}{2009} & - & $\begin{array}{l}\text { Loss of a generalor } \\
\text { Reached Q ampara }\end{array}$ & Install the $3^{\text {rd }}$ generator \\
\hline & \multicolumn{2}{|c|}{$\begin{array}{l}\text { Violation of firm substation capacity } \\
\text { at Polonnaruwa \& Madagama }\end{array}$} & 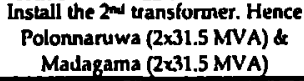 \\
\hline 2010 & - & - & - \\
\hline 2011 & - & - & - \\
\hline 2012 & - & $\begin{array}{c}\text { Ilabarana - Polonnaruwa } \\
\text { Loss di stahility }\end{array}$ & Install the 4th generator \\
\hline 2013 & - & - & - \\
\hline \multirow{3}{*}{2014} & & Habarana - Polonnaruwa & \multirow{2}{*}{$\begin{array}{c}\text { Install 10MVAr at Polonnaruwa } \\
\text { \& } 5 \mathrm{MVAr} \text { at Padirippu }\end{array}$} \\
\hline & & $\begin{array}{c}\text { Un acceptable low voltage } \\
\text { at Polonnaruwa }\end{array}$ & \\
\hline & \multicolumn{2}{|c|}{$\begin{array}{c}\text { Violation of firm substation capacity } \\
\text { at l'adirippu }\end{array}$} & $\begin{array}{c}\text { Install the } 3^{\text {rad }} \text { transformer. Hence } \\
\text { Padirippu (3x31.5 MVA) }\end{array}$ \\
\hline
\end{tabular}

